\title{
Bolivia, Plurinational State of
}

National Cancer Institute

\section{Source}

National Cancer Institute. Bolivia, Plurinational State of. NCI Thesaurus. Code C16359.

A country in central South America, southwest of Brazil. 